Sir-The paper by Benveniste and colleagues $^{1}$ suggesting that the presence of a molecule in aqueous solution can transfer its properties to the solution in the absence of the molecule itself has, as the authors surely anticipated, caused considerable scepticism in our laboratory and others. Most new and revolutionary ideas are initially met with scepticism. But the essence of science is the universality of the principles, and if the ideas presented in this paper are true, they should extend to similar systems.

We have therefore attempted to reproduce the results in a system that models the allergic response. Cells of the cultured rat mast cell tumour line RBL-2H3 were primed with $\operatorname{IgE}$ and loaded with 5-hydroxytryptamine (serotonin), and assayed as previously described ${ }^{2}$, with the modifications described in the figure legend. The figure (representative of three similar experiments) shows that above a dilution of $1 \times 10^{4}$ of the antibody, there was no secretion above the spontaneous release (cells incubated in Hanks' buffer).

We cannot explain the discrepancy between these results and the results presented by the Benveniste group. The RBL-2H3 system we describe is a more

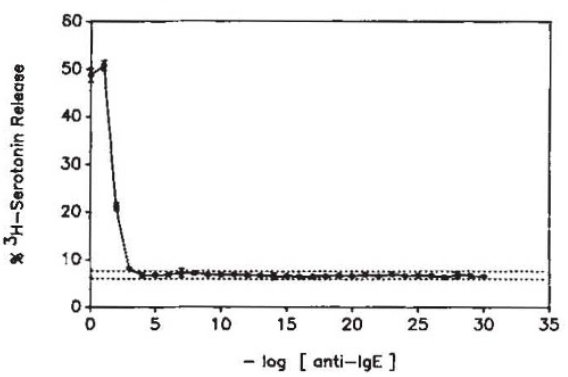

RBL-2H3 cells were primed with $1 \mu \mathrm{g} \mathrm{ml}^{-1}$ monoclonal anti-dinitrophenol mouse $\mathrm{IgE}$ and loaded with $\left[{ }^{3} \mathrm{H}\right]$ serotonin $\left(3 \mu \mathrm{Ci} \mathrm{ml}^{-1}\right)$ for $3 \mathrm{~h}$. The cells were washed and resuspended in modified Hanks' buffer ( $124.5 \mathrm{mM} \mathrm{NaCl}, 4.94$ $\mathrm{mM} \mathrm{KCl}, 0.4 \mathrm{mM} \mathrm{Kh} \mathrm{PO}_{4}, 0.31 \mathrm{mM} \mathrm{Na} \mathrm{HPO}_{4}$, $15.2 \mathrm{mM} \mathrm{NaHCO}, 10 \mathrm{mM}$ HEPES, $1.7 \mathrm{mM}$ $\mathrm{CaCl}_{2}, 0.73 \mathrm{mM} \mathrm{MgSO}_{4}, 5.45 \mathrm{mM}$ glucose, and $0.5 \mu \mathrm{g} \mathrm{ml}^{-1}$ bovine serum albumin, $p \mathrm{H} \mathrm{7.4)} \mathrm{at}$ $5 \times 10^{6}$ cells per ml. Tenfold dilutions of an affinity purified polyclonal anti-mouse $\operatorname{IgE}$ from rabbit serum were prepared in the same buffer, with vortexing for 20 seconds at each dilution as described in ref. 1 . One hundred microlitres of the diluted antibody and one hundred microlitres of the cell suspension were combined in an Eppendorf microfuge tube, and incubated for $20 \mathrm{~min}$ at $37^{\circ} \mathrm{C}$. The secretion was stopped with $0.5 \mathrm{ml}$ of ice-cold phosphatebuffered saline and the cells were pelleted by centrifugation for $2 \mathrm{~min}$ in an Eppendorf microfuge. The serotonin in $0.5 \mathrm{ml}$ of the supernatant was determined by scintillation counting. Assays were performed in triplicate. Error bars are shown where the error exceeded the size of the symbol. The dotted lines indicate the range of spontaneous release (buffer alone), measured at several times during the assay. clearly defined, and probably more sensitive system, in that it uses a pure population of cells in large number $(500,000$ cells per assay as compared with the 60 120 cells counted per assay in the basophil system), a more quantitative assay method (release of labelled serotonin rather than loss of toluidine blue staining cells), a clearly defined IgE, and a purified antibody preparation instead of whole antiserum as reported by Benveniste and colleagues (although the claim is made that similar results were obtained with monoclonal anti-IgE, antigen, phospholipase $\mathrm{A} 2$, and $\mathrm{Na}^{+}$and $\mathrm{Ca}^{2+}$ ionophores). One other, presumably trivial, difference between our study and the previous one are our use of Hanks' buffer instead of Tyrode's. We therefore conclude that, despite the elaborate controls of the previous study, the results do not describe a new scientific principle, but instead must represent, at best, some peculiarity of the assay, and at worst, an intriguing artefact.

JeanClare Seagrave

Cell Pathology Laboratory,

Surge Building,

University of New Mexico,

School of Medicine,

Albuquerque, New Mexico 87131, USA

1. Davenas, E. el al. Nature 333, 816-818 (1988).

Pfeiffer, J.R., Seagrave, J.C., Davis, B.H., Deanin, G. G. \& Oliver, J. M. J. Cell Biol. 101, 2145-2155 (1988).

SrR-We have repeated the experiment reported by Davenas et al. ${ }^{1}$, except that we used histamine release from human basophils rather than basophil degranulation to evaluate the biological effect of a highly diluted anti-IgE, because in several laboratories histamine release is the method of choice. (Benveniste and coworkers themselves, in describing their test, state that basophil degranulation gives results that correlate well with those of histamine release ${ }^{3}$.)

Circulating basophils from a good histamine releaser were separated on a dextran gradient and incubated with increasing dilutions (from $10^{-1}$ to $10^{-45}$ ) of a goat antihuman IgE (anti-Fc, Sigma Chemical, St Louis). Experimental conditions were as described by Davenas et al., including their protocals for shaking the tubes and changing pipette tips. Histamine released in the supernatants was assayed by the automated fluorimetric method ${ }^{3}$, and expressed as per cent of histamine release of the same aliquots of basophils treated with $0.4 \mathrm{M}$ perchloric acid. As expected, a good histamine release was observed between $10^{-1}$ and $10^{-4}$ dilutions of antiIgE, with a dose-response curve ranging from 53 per cent to 6 per cent of histamine release.

However, no histamine release was observed for any further dilution. Repeat- ing the experiment gave highly reproducible results.

We therefore conclude that the findings of Davenas et al. cannot be extended to another technique. Should we speculate why water can remember something on some occasions and forget it on others? As your editorial states: "It will be time for celebrations of that kind only when a lot more water has run underneath this bridge". . . and on laboratory desks.

SERGio Bonini

EMILIO Adriani

FRANCESCO BALSANO

Andrea Cesalpino Foundation and

Institute of Clinica Medica 1st,

University of Rome "La Sapienza", 00161 Rome, Italy

1. Davenas E. et al. Nature 333, 816 (1988)

2. Benveniste, J. Ouest Med. 30, 467 (1977)

3. Siraganian, R.P. Analyt. Biochem. 57, 383 (1974)

4. Nature 333, 787 (1988)

SIR-So now at last confirmation of what I have always suspected. Papers for publication in Nature are refereed by the Editor, a magician and his rabbit.

Department of Biochemistry,

KeITH SNELL

University of Surrey,

Guildford, Surrey GU2 5XH, UK

\section{Regulating IVF}

SIR-In the report "International outlook for embryo research" (Nature 333, 791; 1988) there were a number of misrepresentations regarding the complex regulatory climate in Australia.

There is no in vitro fertilization (IVF) legislation as such in Australia, since medical issues are decided state-by-state, and not on a Commonwealth basis. Only two states have passed laws regarding IVF, namely Victoria and South Australia. In the other states, IVF is governed by selfregulation under the auspices of the National Health and Medical Research Council. The only stipulations are that embryos should not be kept in culture beyond 14 days, and that local institutional bioethics committees should authorize the work.

The Victorian IVF law had been passed by the parliament in that state in 1984 , but the vital section of the law dealing with embryo research was not proclaimed until 1 July 1988. According to the now valid law, research can only be performed with spare embryos left over in IVF treatments of infertile patients. Moreover, such research can only be conducted if prior approval had been obtained from a review committee set up by the Health Minister of Victoria.

Between its formulation in 1984 and proclamation in 1988 , the original law was amended in an important way. As the law now stands, up to the stage of syngamy 
when the male and female nuclei fuse, the zygote is not regarded as an embryo. This means that the prohibition of creating embryos for research does not apply to the first 20 hours. Dr Trounson and his colleagues at Monash University in Victoria have requested this amendment from the minister on the basis that the 20-hour gap will give them sufficient time to test whether micro-injection of deficient sperm into the egg results in a chromosomally defective zygote.

Based on these tests, Trounson and his colleagues plan to go ahead and insert micro-injected eggs into the uterus of infertile women (or of fertile women in the case of infertile partners). Indeed, they have already done this earlier this year. As the law stands, the insertion of microinjected eggs into the uterus of a patient in an IVF programme is not regarded as research, and hence does not need the approval of the Victorian IVF review committee. It is assumed that premature work would be stopped by the local bioethics committee. In the micro-injection case just mentioned this had not happened and so the work had gone ahead.

Clearly embryo research laws are very difficult to formulate in such a way that they encapsulate all that a parliament may wish to have regulated. It is hoped that the less than satisfactory legal situation in Victoria will serve Britain as a useful lesson for how not to draft such legislation.

DitTta BARTEls School of Science \& Technology Studies, The University of New South Wales, PO Box 1, Kensington,

New South Wales, Australia 2033

\section{German angle}

SIR-The leading article regarding the Embryo Protection Law being formulated by the West German Justice Ministry (Nature 333, 787; 1988) was loaded with subjective comments, which are indeed matters of opinion and not incontrovertible. To take them in order:

It is indeed a "paradox that research should be singled out" for this legislation. Clearly this does not prove that the legislation is unnecessary. It may just need to be extended in scope.

- Our understanding of the ethical implications of medical research lags far behind our technological progress. A degree in biochemistry is not a qualification in moral philosophy, and the idea that researchers should or can "police themselves" is ill-founded at best, especially as profit, prestige and prizes are available to motivate those who break the rules.

- I disagree that it is small consolation to the research community for "history and the legal system" to provide restraint to scientific research. Civilized society must look to the mistakes of the past and protect itself from making the same mistakes in the future. Research in a society devoid of such constraints would be intolerable.

The article concludes by implying that the West German people should "appreciate that embryo research may, in due course ... rid people of undignifying genetic diseases". We are a long way from curing anyone of a genetic disease, but have already begun ridding ourselves of PEOPLE, with what we consider "undignifying genetic diseases", through abortion and euthanasia. How similar that sounds to the rationale used by the Nazis to attempt the genocide of the Jewish race.

It is my sincere hope that generations to come will not have cause to condemn us for crimes which they view in the same way as we now view the crimes of Nazi Germany.

Kenneth W. M. Cochran AT\&T Bell Laboratories,

200 Laurel Avenue,

Middletown,

New Jersey 07748, USA

\section{Moratorium call}

SIR-We read with deep concern the letter by Braude et al. (Nature 332, 459-460; 1988) regarding the activation of the human embryonic genome. We feel that in this study the ethical bounds of scientific work have been overstepped.

Although biologists have developed techniques to manipulate mammalian embryos, the abuse of these techniques through experiments with human embryos (or pre-embryos, if one considers a preimplantation embryo not to be an embryo) must be condemned by the scientific community. Scientists cannot wait for public or political pressure to define the limits of their work. The time has come for an Asilomar-type moratorium to establish ethical boundaries for work on human embryos.

In our opinion this study is unethical. We think therefore that experiments of this kind should not be encouraged by their publication in any journal, including Nature.

(This letter represents the views of the undersigned senior scientists or graduate students, and should not be construed as necessarily representative of the views of the institute or the society for which we work.)

Rudi Balling, Kamal Chowdhury,

Urban Deutsch, Susanne Dietrich, UWE Drescher, UlF HENSEling,

Birgit Jostes, Gunnar-Ingi

Kristuansson, Tine de Maeyer, Andreas Püschel, Hans Schöler, Daria Siekhaus, Franz Theuring, Claudia Walther, Andreas Zimmer

Department of Cell Biology,

Max-Planck-Institute of Biophysical Chemistry,

Göttingen, FRG

\section{Conservation plan}

SIR-I was interested in your leading article (Nature 333, 284; 1988) outlining the problem of OECD food subsidies.

A possible useful way of harnessing the excess production would be to give or sell the food to developing countries at a reduced rate in return for land/forest conservation programmes. A scheme involving third world debt/conservation exchange seems to be working well.

The idea has a lot going for it. For example, the OECD farmers would be working for the retention of the remaining virgin land on this planet instead of purely for government hand-outs.

25 Avenue Athol,

R. G. H. CotTon

Canterbury,

Victoria 3126, Australia

\section{New OSHA standards}

SIR-You report (Nature 333, 590; 1988) that OSHA has set new permissible exposure limits for more than 400 chemicals. In fact, the agency has proposed new limits.

We are currently holding hearings on the proposal which should be completed by mid-August. We hope to issue a final standard for these chemicals before the end of the year.

Akio Konoshima

US Department of Labor,

Occupational Safety and Health

Administration,

Washington, DC 20210, USA

\section{Ozone layer}

SiR-Why not pressurize spray-cans with ozone?

14 Salisbury Court,

Salisbury Avenue,

London N3 $3 A H, U K$

\section{Cover blown}

SIR-Wordsworth wrote: "Little we see in Nature that is ours". Indeed, the picture appearing on the cover of the issue of 7 July, attributed to us, is not our work.

Arthur M. Lesk VICTOR I. LESK

\section{Field Way, Cambridge, UK}

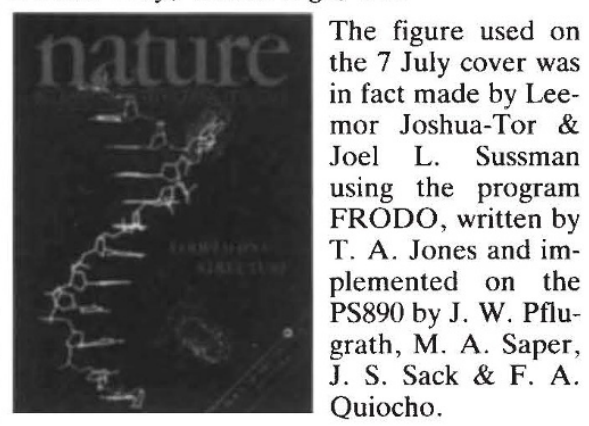

